\begin{tabular}{|c|c|c|}
\hline Beitr. Ent. & Keltern & ISSN 0005-805X \\
\hline $\mathbf{5 5}(2005) 2$ & S. $477-484$ & 27.12 .2005 \\
\hline
\end{tabular}

\title{
Repatriation of knowledge about insects and types through the DORSA virtual museum
}

\section{(Digital Orthoptera Specimen Access)}

With 4 figures

\author{
Karl-Heinz Lampe, Klaus Riede and Sigfrid Ingrisch
}

\begin{abstract}
Summary
DORSA (Digital Orthoptera Specimen Access) is a virtual museum joining information on Orthoptera types and voucher specimens scattered over the major German museum collections in a single database. Data for about 16,000 specimen records including types and vouchers in over 4,000 species are searchable online via the SYSTAX database (www.biologie.uni-ulm.de/systax) which is linked to both the GBIF (Global Biodiversity Information Facility)- and BIOCASE (Biological Collection Access Service for Europe)- portals. Roughly 8,000 type specimens (with about 2,300 primary types) are documented with over 30,000 images. 12,000 sound files are also available as are geographical information and maps of the specimens in the database. DORSA specimen information is reciprocally linked to the Orthoptera Species File (OSF) which forms the taxonomic backbone for all taxon names used by DORSA. All DORSA data are freely available on the world-wide web. In this way, the knowledge about type specimens collected since colonial times is repatriated to the countries of origin.
\end{abstract}

\section{Zusammenfassung}

DORSA (Digital Orthoptera Specimen Access) ist ein virtuelles Museum, das Informationen über Typus-Exemplare von Orthopteren und andere Belege, welche über die wichtigsten deutschen MuseumsSammlungen verstreut sind, in einer einzigen Datenbank zusammenführt. Etwa 16.000 Individuen-Einträge aus über 4.000 Arten sind über das Internet in der SYSTAX-Datenbank (www.biologie.uni-ulm.de/systax) suchbar. SYSTAX stellt die Daten auch über die GBIF (Global Biodiversity Information Facility)- und BIOCASE (Biological Collection Access Service for Europe)- Portale bereit. Etwa 8.000 Typus-Individuen (davon 2.300 primäre Typen) sind mit über 30.000 Fotos dokumentiert. Die Datenbank enthält ferner 12.000 Tonaufnahmen. Fundortdaten und Verbreitungskarten der gespeicherten Individuen sind ebenfalls abrufbar. Die DORSA Individuendaten sind reziprok mit dem Orthoptera Species File (OSF) verbunden; dieses bildet zugleich das taxonomische Rückrat für DORSA. Alle DORSA Informationen sind frei über das Internet verfügbar. Auf diese Weise wird das Wissen über die Typus-Individuen, die seit der Kolonialzeit gesammelt worden waren, in die Herkunftsländer repatriiert.

\section{Keywords}

Orthoptera, DORSA, SYSTAX, OSF, specimen database, type information, virtual museum, repatriation of knowledge. 
Taxonomic literature is scattered over numerous journals and books which are often not easily available because most of the classical references but also many of the new publications are held only in a few libraries worldwide. A recent bibliography on Orthoptera lists over 14,000 titles with taxonomic significance (INGRISCH \& WILLEMSE 2004). Moreover the knowledge of the diversity of insects has greatly multiplied since the introduction of the binominal nomenclature nearly 250 years ago. For the Orthoptera alone, the number of known species raised from only 59 taxa in LinNes' (1758) genus Gryllus to almost 30,000 species group names that are currently listed in the Orthoptera Species File (osf2x.orthoptera.org). Together with the increase of knowledge, the definitions of the species concept has changed repeatedly and taxonomic methods have shown great progress. It is thus understandable that historical descriptions are usually insufficient to identify specimens at hand. Fortunately, descriptions of biological species are based on type specimens. In former times, travelling to several museums or loan of specimens were necessary to compare specimens for identification of new material. With the rise of the world-wide web, it is now possible to provide museum information on-line, thereby facilitating access to type material, pictures or any other information related with type specimens (RIEDE 2003).

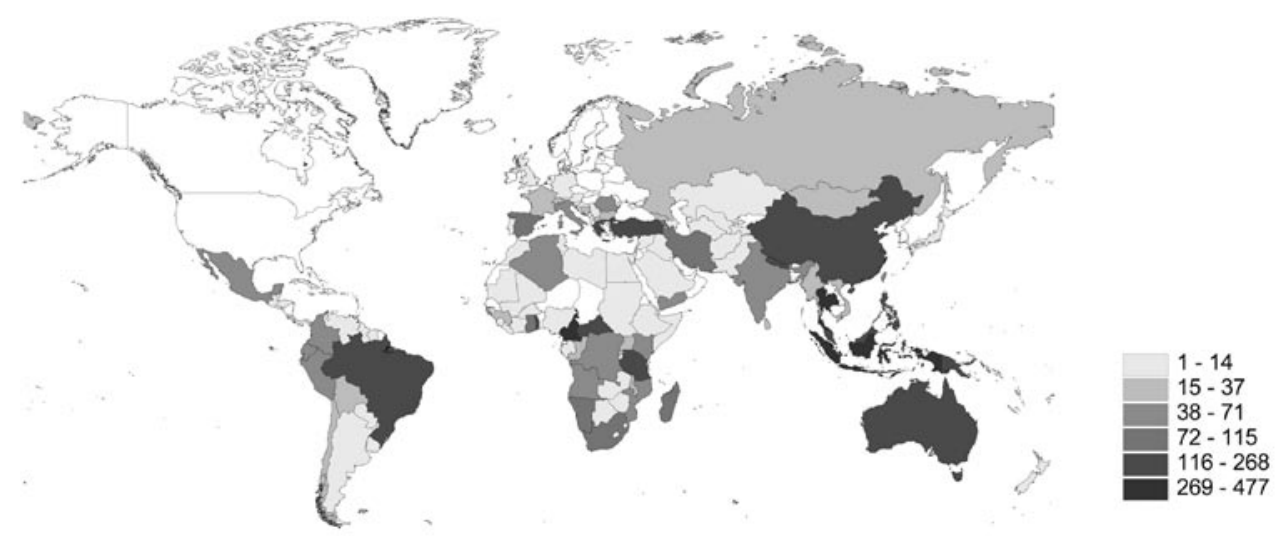

Fig. 1: Distribution of Orthoptera type specimens (including Para- and Lectotypes) housed in German Museum collections. Note the high number of types from Africa, South East Asia and Australia, collected in the last centuries. [From Riede 2003].

German researchers shared a significant part in exploring the Orthoptera fauna of the world. Examples for significant historical expeditions are those of Hemprich and Ehrenberg to North Africa and West Asia (Kuvg 1830-1832), Buchholz 1872-1875 to Guinea (Gerstaecker 1883), Graeff 1879-1880 to Guinean islands (Krauss 1890), Preuss 1891 to Cameroon (Karsch 1891a, b), Kling and Büttner 1888-1891 to Togo (Karsch 1894), Kükenthal 1893-1894 to the Malayan Archipelago (BrunNer 1898), Voeltzkow 1889-1895 to Madagascar (Saussure 1899), Filchner to China and Tibet 1903-1905 (Karny 1908), Schlaginhaufen to New Guinea (Karny 1912), the German Central-Africa Expedition 1907-1908 (ReHn 1914), the Kaiserin-AugustaflussExpedition to New Guinea 1912-1913 (e.g. KARNY 1928), and Ramme's revisions of African, Southeast Asian, Southeast European and West Asian Acrididae (e.g. Ramme 1929, 1941, 1951). Due to those and many others including modern expeditions, 
German museum collections hold type specimens from all over the world (Fig. 1) and account for about ten percent of the species group names in Orthoptera, but the relative numbers vary between subgroups (INGRIsCH et al. 2004a, Fig. 2).

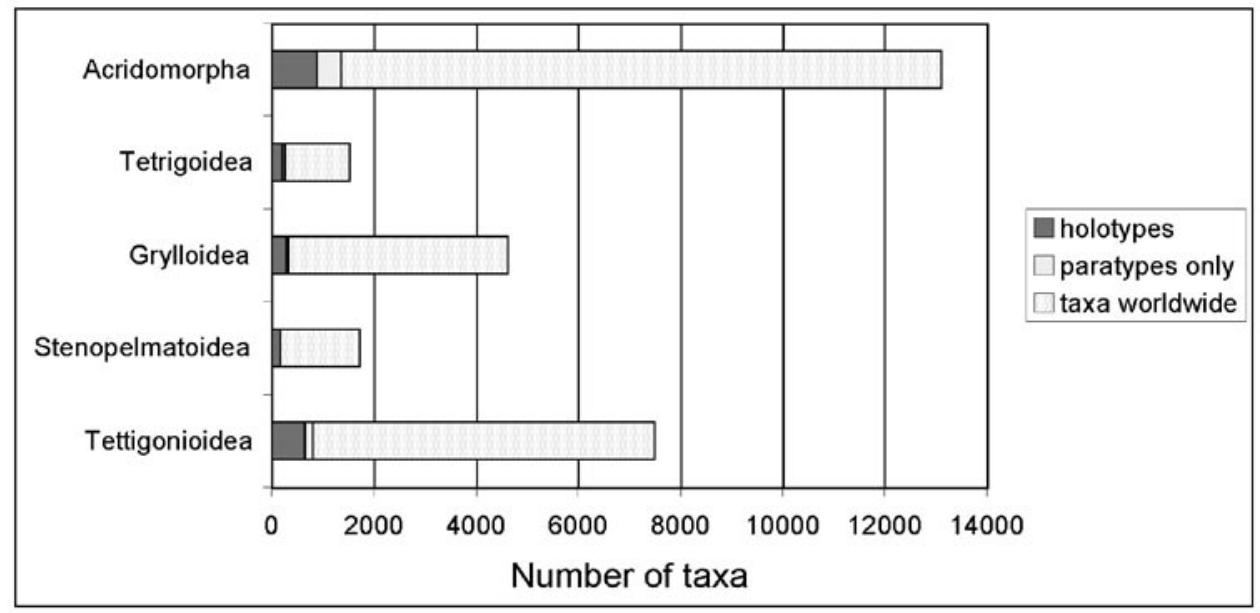

Fig. 2: Species group names of Orthoptera worldwide (valid names and synonyms) and types specimens in German collections. The category holotype includes also syntypes, lectotypes and neotypes. [From Ingrisch et al. 2004a].

Due to the federal political landscape of Germany, there are several museum collections of similar importance, which means that the material is even more scattered than in other European countries, such as Great Britain and France (Fig. 3). This scattered information was digitised and published on the world-wide web as one "Virtual Museum" by DORSA (Digital Orthoptera Specimen Access) thus facilitating access and providing a "virtual centralisation". The type specimens information is provided together with images and songs. The Orthoptera Species File (OSF, EAdes 2001) forms the taxonomic backbone for all taxon names used by DORSA. OSF stores the original name as well as the currently valid name together with general information on the type specimens.

There is a fundamental difference between both databases. Species databases deal with names (taxa), i.e. human concepts (OSF). Specimen based databases deal with real world objects, such as pinned museum specimens (DORSA). Both databases are linked by the type specimen which is the real world voucher on which a species description is based. DORSA and OSF are two separate relational databases, optimised to administer specimens and names (taxonomic concepts), respectively. Cooperation between and linking of both databases allowed multiple verification of the data. The species database gets its data mainly from published information while the specimen database collects its information from the specimens in the collection and the labels. When both sets of data disagreed, a closer investigation on the fate of the type specimens became necessary. As a result, type specimen information in OSF could be updated with the information provided by DORSA, while the information in OSF helped to discover type specimens in museum collections that were not properly labelled (INGRISCH et al. 2004b). 


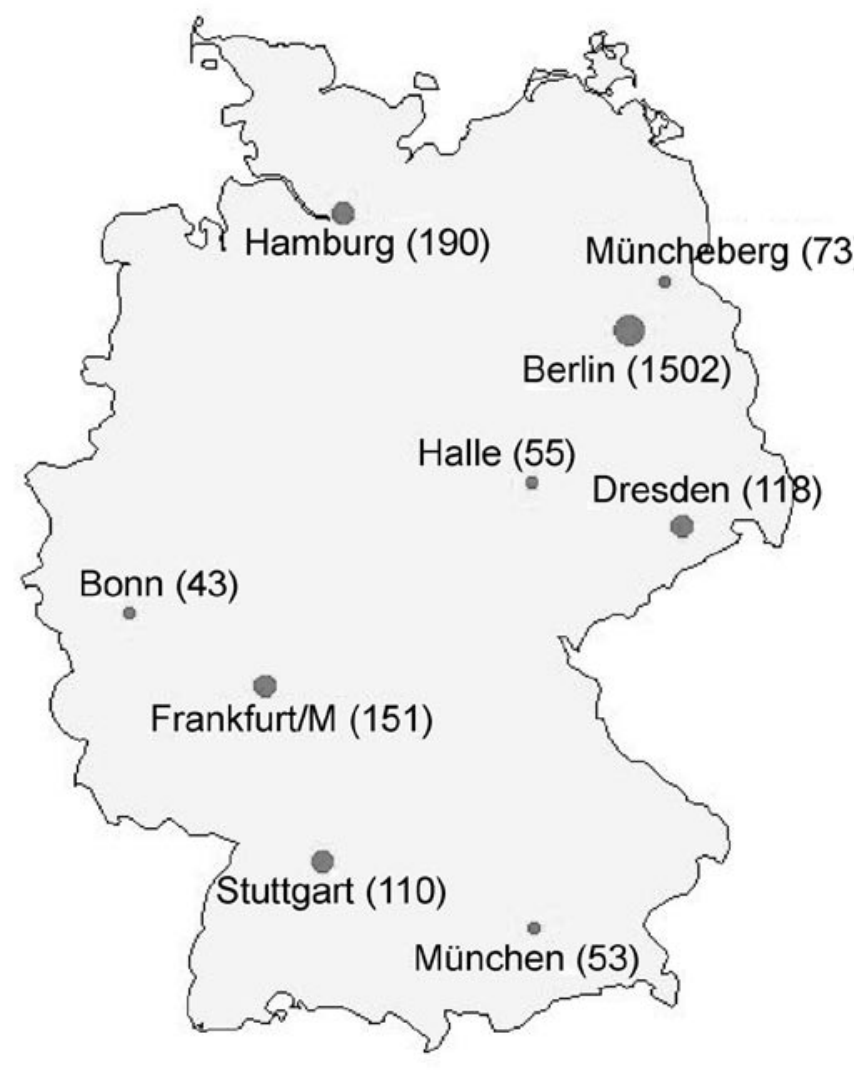

Number of Holotypes:

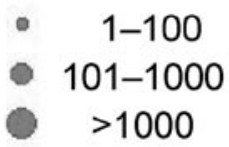

Fig. 3: Orthoptera (crickets and grasshoppers) collections in Germany - number of holotypes in major museums. A similar distributed pattern is observed for type material of other groups of organisms housed in German museums or research institutions.

DORSA compiles data from over 8,000 type specimens of which about 2,300 are primary types in almost 3,000 species. Additional voucher specimens for sound recordings and important taxonomic revisions are also included which totals in about 16,000 specimen records in over 4,000 species (Tab. 1). Moreover, 30,000 images of type specimens and 12,000 sound files are included in the DORSA documentation. The sound files were provided by private researchers and became publicly available through DORSA. Sound files help to identify living specimens in the field, as Orthoptera songs can only be paraphrased in printed journals which does not give the same impression as hearing the sound itself. Label information is included in the documentation, to track mistakes during data-basing.

All DORSA data are freely available over the SYSTAX database (www.systax.de). In this way, the knowledge on the type specimens collected since the colonial times is also repatriated to the country of origin. The data provided by DORSA can be easily accessed from a variety of sources over the world-wide web. SYSTAX is linked to GBIF (Global Biodiversity Information Facility; www.gbif.org) and BIOCASE (Biological Collection Service for Europe, www.biocase.org). Moreover, DORSA specimen information is re- 
Tab. 1: Registration of type specimens of Orthoptera without Tridactyloidea in German museum collections by February 2004. Collaborating museums: ZMB Berlin, DEI Müncheberg, SMTD Dresden, ZMH Hamburg, MLUH Halle, ZFMK Bonn, SMF Frankfurt, SMNS Stuttgart, ZSM München.

\begin{tabular}{|c|c|c|c|c|c|}
\hline museum & $\begin{array}{c}\text { taxa with pri- } \\
\text { mary types }\end{array}$ & $\begin{array}{l}\text { taxa with types in- } \\
\text { cluding paratypes }\end{array}$ & $\begin{array}{c}\text { number of type } \\
\text { specimens }\end{array}$ & $\begin{array}{l}\text { total record- } \\
\text { ed species }\end{array}$ & $\begin{array}{l}\text { total record- } \\
\text { ed specimens }\end{array}$ \\
\hline Berlin & 1502 & 1916 & 5418 & 2207 & 6320 \\
\hline Müncheberg & 73 & 140 & 408 & 164 & 445 \\
\hline Dresden & 118 & 167 & 511 & 279 & 856 \\
\hline Hamburg & 190 & 269 & 435 & 324 & 553 \\
\hline Halle & 55 & 55 & 75 & 91 & 151 \\
\hline Bonn & 43 & 50 & 166 & 89 & 274 \\
\hline Frankfurt & 151 & 179 & 334 & 273 & 553 \\
\hline Stuttgart & 110 & 129 & 599 & 147 & 658 \\
\hline München & 53 & 84 & 232 & 101 & 382 \\
\hline Sum $^{1}$ & 2295 & 29891 & 8178 & 36751 & 10192 \\
\hline Voucher-Specimens ${ }^{2}$ & 66 & 160 & 673 & 866 & 5788 \\
\hline Sum $^{1}$ & 2309 & 29351 & 8851 & 40571 & 15980 \\
\hline
\end{tabular}

${ }^{1}$ settled [species with specimens in several collections are counted only once]

${ }^{2}$ Voucher-Specimens for sound records

ciprocally linked to the Orthoptera Species File (OSF). Information about type material in German museums can be retrieved both ways - via SYSTAX, or via OSF, the latter includes all synonyms and taxonomic references (Fig. 4). As OSF now works as the supplier of systematic information on Orthoptera in biodiversity projects as Species 2000 (www.sp2000.org), ITIS (www.itis.usda.gov), NCBI (National Center for Biotechnology Information, used by Genbank), and indirectly the Catalogue of Life and GBIF, DORSA specimens information can also be traced from those sources.

The geographic information for many specimens in DORSA had to be actualised as the information given on labels was either not precise or the names of places or their affiliation to countries had changed since the time of collection. Fortunately several expedition reports allowed the tracing of localities with sufficient precision. Thus a majority of the locality data could be geo-referenced with latitude/longitude co-ordinates $(3,100$ out of the roughly 5,800 locality data). This will help future users to find this information easily, and it allows mapping by a geographical information system (GIS). Distribution maps are available from the Dorsa Map Server (www.dorsa.de) which is based on approximately 1,200 localities of katydid (Tettigonioidea) sound records made by K.-G. Heller (cf. Willemse \& Heller 2001) and for all type specimens via SYSTAX which uses the Canadian Biodiversity Information Facility (www.cbif.gc.ca/home_e.php). 


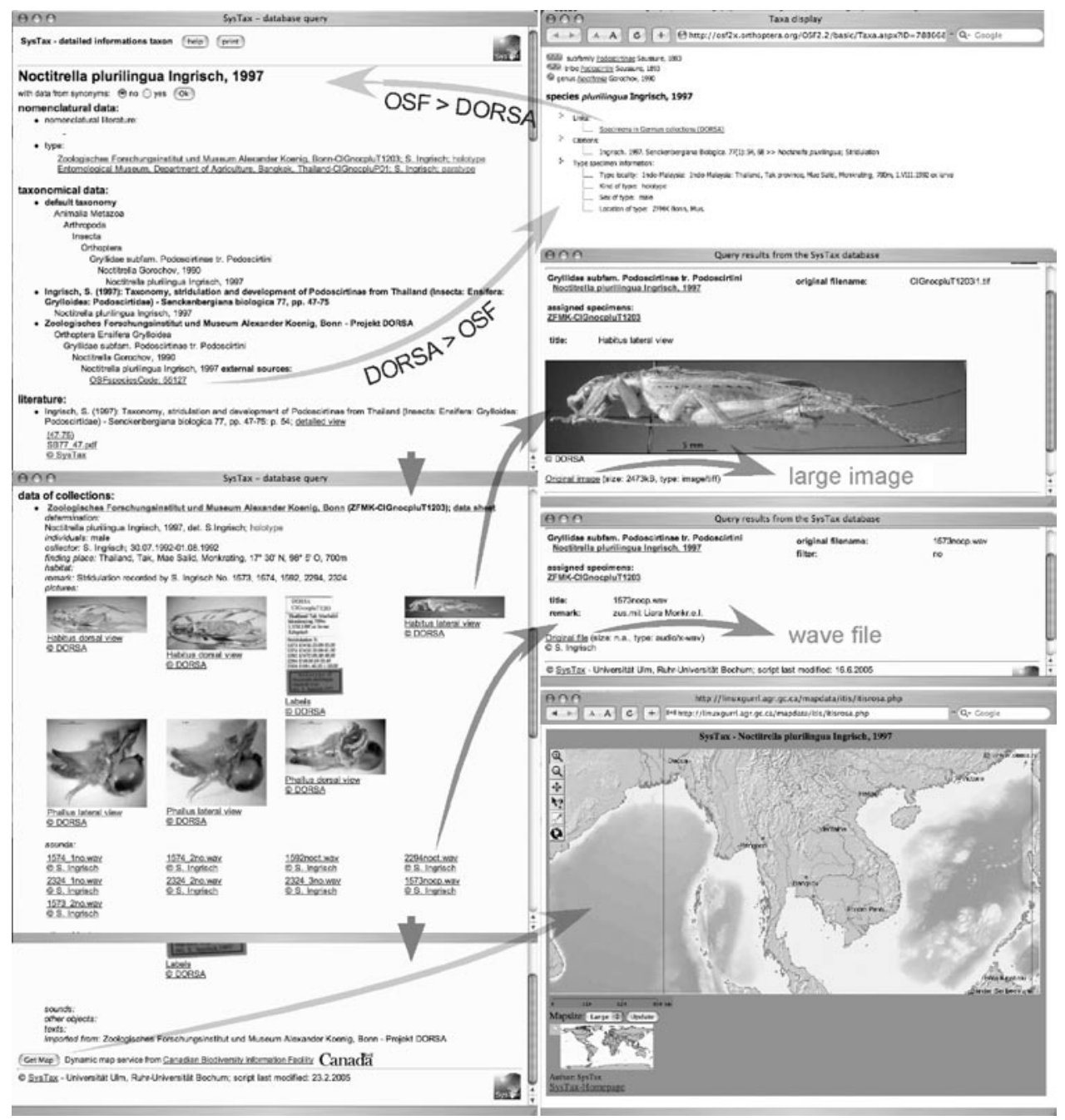

Fig. 4: Documentation of DORSA specimen data on the internet. Left: species page in SYSTAX (red arrows mark scrolling down); top right: species page in OSF; middle right: image and sound file pages in SYSTAX; bottom right: distribution map from a map server (Canadian Biodiversity Information Facility). External links are marked by yellow arrows, internal links by green arrows.

A cricket song classification software was developed, based on neural networks trained by data based song (for details see Palm \& DieTrich 2001). It can be used in rapid assessment programs, as a non-invasive technique to classify and map acoustic diversity in the field. To put this useful tool into practise, it should now be calibrated by new sound data from a representative number of species in a given area. In many areas of the world that means recordings have to be made together with collecting of specimens and taxonomic revisions. 


\section{Acknowledgements}

From April 2000 to March 2003, DORSA was funded by the German Federal Ministry of Education and Research (BMBF). Our special thanks go to the curators of the museums for their cooperation when digitizing the specimen data. D. Eades (Illinois Natural History Survey) cooperated with linking of DORSA to OSF.

\section{References}

Brunner von Wattenwyl, C. 1898: Orthopteren des Malayischen Archipels, gesammelt von Prof. Dr. W. KüKENTHAL in den Jahren 1893 und 1894. - Abhandlungen der Senckenbergischen Naturforschenden Gesellschaft, Frankfurt/M. 24: 193-288, pls 16-20.

EADEs, D. C. 2001: Version 2 of the Orthoptera species file online. - Journal of Orthoptera Research 10: 153-163.

Gerstaecker, A. 1883: Beitrag zur Kenntniss der Orthopteren. Fauna Guinea's nach dem von R. Buchholz wahrend der Jahre 1872 bis 1875 daselbst gesammelten Arten. - Mittheilungen aus dem naturwissenschaftlichen Verein für Neu-Vorpommern 14: 39-102; Greifswald.

Ingrisch, S. \& Willemse, F. 2004: Bibliographia Systematica Orthopterorum Saltatoriorum. Systematic bibliography of saltatorial Orthoptera from Linnaean times to the end of the 20th century (includes a reference database on CD-ROM). - Pensoft, Sofia: 536 pp.

INGRISCH, S.; RIEDE, K. \& LAMPE, K.-H. 2004a: DORSA - virtuelles Museum deutscher Orthopterensammlungen online. - Mitteilungen der Deutschen Gesellschaft für Allgemeine und Angewandte Entomologie 14: 479-482.

Ingrisch, S.; Riede, K.; Lampe, K.-H. \& Dietrich, C. 2004b: DORSA - A “Virtual Museum” of German Orthoptera Collections. - Memorie della Società Entomologica Italiana 82 [2003]: 349-356; Genova.

Karny, H. H. 1908: Hexapoda. 1. Orthoptera. A. Dictyoptera, Tettigonioidea, Acridoidea. - In: Wissenschaftliche Ergebnisse der Expedition Filchner nach China und Tibet 1903-1905 10.1.1. - Berlin: Ernst Siegfried Mittler und Sohn, 1-56, pls 1-2.

Karny, H. H. 1912: Conocephaliden (Orthoptera Locustoidea) aus Neuguinea hauptsächlich gesammelt von Dr. O Schlaginhaufen. - Abhandlungen und Berichte des zoologischen und anthropologisch-ethnographischen Museums zu Dresden 14: 3-23.

Karny, H. H. 1928: Ueber die Gryllacriden der Deutschen Kaiserin Augustafluß-Expedition 1913. Mitteilungen aus dem Zoologischen Museum Berlin 14: 83-114, pls 3-4.

Karsch, F. 1891a: Uebersicht der von Herrn Dr. Paul Preuss auf der Barombi-Station in Kamerun gesammelten Locustodeen. Als Anhang: Ueber die Mecopodiden (pp. 341-346). - Berliner Entomologische Zeitschrift 36: 317-346; Berlin.

Karsch, F. 1891b: Verzeichniss der von Herrn Dr Paul Preuss in Kamerun erbeuteten Acridiodeen. - Berliner Entomologische Zeitschrift 36 (1): 175-196; Berlin.

Karsch, F. 1893: Die Insecten der Berglandschaft Adeli im Hinterlande von Togo (Westafrika) nach dem von den Herren Hauptmann Eugen Kuing (1888 und 1889) und Dr. Richard Büttner (1890 und 1891) gesammelten Materiale bearbeitet. - Berliner Entomologische Zeitschrift 38: 1-266, pls 1-6; Berlin. Abteilung: Apterygota, Odonata, Orthoptera Saltatoria, Lepidoptera Rhopalocera.].

KLUG, J. C. F. 1830-1832 [1929-45]: Symbolae physicae seu icones et descriptiones Insectorum, quae ex itinere per Africam borealem et Asiam occidentalen Friderici Guilelmi Hemprich et Christiani Godofredi Ehrenberg medicinae et chirurgiae doctorum studio novae aut illustratae redierunt. - In: НEmprich, F. G. \& Ehrenberg, C. H.: Symbolae Physicae Zool. 2 (Insect. 3): Decas prima , fol. a-i, pls 1-10 [no Orthoptera](1829); Decas secunda, fol. a-f, pls. 11-20 (1830); Decas tertia, fol. a-l, pls. 21-30 (1832) - Berlin.

Krauss, H. A. 1890: Beitrag zur Kenntnis westafrikanischer Orthopteren. 2. Orthopteren der Guinea-Inseln São Thomé und Rolas, gesammelt von Prof. Dr. Richard Graeff. - Zoologische Jahrbücher, Abteilung für Systematik, Oekologie und Geographie der Tiere 5: 647-668, pl. 43. 
Linnaeus, C. 1758: Systema Naturae, per Regna tria Naturae secundum Classes, Ordines, Genera, Species, cum Characteribus, Differentiis, Synonymis, Locis. (10th ed.). 1. - Laurentius Salvius: Holmiae [Stockholm]: ii + 824 pp. [Facsimile edition 1956, British Museum (Natural History), London].

Palm, G. \& Dietich C. 2001: Automated Identifiation of Bioacoustic Signals, Biolog Statusseminar, Bonn (foils in pdf format: http://www.bgbm.fu-berlin.de/BioDivInf/biolog/Statusseminar1/20011206-B1Palm-DORSA.pdf).

Ramme, W. 1929: Afrikanische Acrididae. Revisionen und Beschreibungen wenig bekannter und neuer Gattungen und Arten. - Mitteilungen aus dem Zoologischen Museum Berlin 15: 247-492, pls 1-16.

Ramme, W. 1941: Beiträge zur Kenntnis der Acrididen-Fauna des indomalayischen und benachbarter Gebiete (Orth.) mit besonderer Berücksichtigung der Tiergeographie von Celebes. - Mitteilungen aus dem Zoologischen Museum Berlin 25 [1940]: 1-243, pls 1-21.

Ramme, W. 1951: Zur Systematik, Faunistik und Biologie der Orthopteren von Südost-Europa und Vorderasien. - Mitteilungen aus dem Zoologischen Museum Berlin 27: 1-432, pls 1-39.

Renn, J. A. G. 1914: Orthoptera. I. Mantidae, Phasmidae, Acrididae, Tettigoniidae und Gryllidae aus dem Zentral-Afrikanischen Gebiet, Uganda und dem Ituri-Becken des Kongos. - Wissenschaftliche Ergebnisse der deutschen Zentral-Afrika Expedition, 1907-1908, Leipzig, 5 (Zool. 3 [1]): 1-223.

RIEDE, K. 2003: Biodiversity Informatics in Germany: ongoing projects and their possible contribution to the Global Taxonomy Initiative (GTI). - In: Junko Shimura (ed.). Global Taxonomy Initiative in Asia. - National Institute for Environmental Studies, Japan: 294-300.

Saussure, H. de 1899: Wissenschaftliche Ergebnisse der Reise in Madagaskar und Ostafrika in den Jahren 1889-95 von Dr. A. Voeltzkow. Orthoptera. - Abhandlungen der Senckenbergischen Naturforschenden Gesellschaft, Frankfurt/M. 21: 569-664, pls 37-38.

Willemse, F. \& Heller, K.-G. 2001: Two new species of Eupholidoptera Maran (Orthoptera, Tettigoniidae) from Crete with a checklist and key to the species. - Tijdschrift voor Entomologie 144: 329-343; Amsterdam (Nederlandse Entomologische Vereniging).

\section{Authors' address:}

Karl-Heinz Lampe, Klaus Riede \& Sigfrid Ingrisch

Zoologisches Forschungsmuseum Alexander Koenig (ZFMK)

Adenauerallee 160

D-53113 Bonn

e-mail: k.lampe.zfmk@uni-bonn.de; k.riede.zfmk@uni-bonn.de; sigfrid.ingrisch@planet-interkom.de 